\section{Improving Irrigation Water Use in Container Nurseries}

\author{
Hannah M. Mathers ${ }^{1}$, \\ Thomas H. Yeager ${ }^{2}$, and
}

Luke T. Case ${ }^{1}$

AdDITIONAL INDEX WORDs. application efficiency, cyclic irrigation, irrigation scheduling

Summary. As limitations on water used by container nurseries become commonplace, nurseries will have to improve irrigation management. Several ways to conserve water and improve on the management of irrigation water applied to container plants are discussed in this review. They include 1) uniform application, 2) proper scheduling of irrigation water, 3) substrate amendments that retain water, 4) reducing heat load or evaporative loss from containers, and 5) recycling runoff water.

\section{Overhead sprinkler irrigation}

$\mathrm{O}$ verhead irrigation is the most commonly used irrigation system for container production of woody ornamentals (Beeson and Knox, 1991). Overhead irrigation system infrastructure allows for a lot of flexibility with regard to the number of container plants and size of plants that can be irrigated within an area. However, the limited root zone of container plants requires frequent replenishment of water, and this impacts the irrigation application efficiency of overhead sprinkler irrigation systems. Irrigation application efficiency is defined as the amount of water applied that is in the root zone and available for plant use. Irrigation system infra-

Salaries and research support provided by state and federal funds appropriated to the Ohio Agricultural Research and Development Center, The Ohio State University. Manuscript number HCS 03-37. We acknowledge the technical assistance provided by Jenny Pope and James Beaver in the preparation of this manuscript.

${ }^{1}$ Department of Horticulture and Crop Science, Ohio State University, Columbus, OH 43210-1096; mathers.7@osu.edu

${ }^{2}$ Department of Environmental Horticulture, IFAS, University of Florida, Gainesville, FL 32611-0670; tyeager@mail.ifas.ufl.edu structure, container plant spacing, and container substrate physical characteristics, as well as the uniformity of irrigation water application, impact the application efficiency. For example, the surface area of \# I containers [American National Standards Institute (ANSI), 1996] without plants placed adjacent to each other in a square pattern covers about $79 \%$ of the land surface area (Furuta, 1974). These same containers with a distance between them of 15.2 $\mathrm{cm}$ (6 inches) cover about $20 \%$ of the land surface area. Thus, $80 \%$ of the overhead sprinkler irrigation water is potentially lost between the containers unless recycled. Beeson and Knox (1991) found that only $57 \%$ to $70 \%$ of overhead irrigation with \#1 containers, depending on crop, plant spacing, and sprinkler type, reached the substrate surface. Weatherspoon and Harrell (1980) found that during the production period only $13 \%$ to $26 \%$ of the irrigation water applied was retained and did not run off. Whenever possible, containers should be placed beside each other because more water will reach the container surface vs. falling between the containers. This will dramatically increase water application efficiency compared to wider spacing.

UNIFORM OVERHEAD IRRIGATION APPLICATION. The uniformity of water delivery is an important component of efficient irrigation application. Distribution pattern or distribution uniformity (DU) is a measure of how uniformly water is applied to an area irrigated with overhead sprinklers. If the sprinkler system does not apply water uniformly, often the irrigation duration is increased, sometimes excessively (B. Lane, personal communication), to compensate for drier areas. But this results in excess water applied in part of the irrigated area and leaches nutrients from containers. By conducting water distribution tests under the normal operating and environmental conditions of the irrigation system, nursery managers can obtain the data required to determine the water distribution and the water application rate. A DU $\leq 80 \%$ indicates that adjustments are needed in the delivery system infrastructure (Haman et al., 2003), such as replacing worn nozzles or replacing nozzles with ones appropriate for the irrigation design, and removing debris from nozzles and filters to achieve proper sprinkler rotation and operating pressure.

A minimum of 16 cups placed in a grid pattern between sprinklers can be used to determine DU (Haman and Yeager, 2003a). Cups are placed uniformly throughout irrigated sprinkler overlap in a grid pattern with a minimum of 16 cups randomly located between sprinkler risers. The more cups used to form a square grid, the better. The number of cups should be in multiples of four (i.e., 16, 24, 32, 64, etc.) and each cup should not exceed

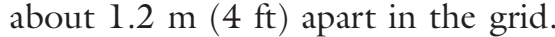
The sprinkler system is operated for a set period of time; the water volumes in the cups are collected and measured. During the uniformity test, record wind speed and direction, nozzle and pump pressure; note location and type of nozzles, and irrigation duration. The DU test should be conducted in several areas close to the pump and at the farthest distance from the pump.

Distribution uniformity is defined as

$\mathrm{DU}=\frac{\text { Avg of lowest volume quartile }}{\text { Avg volume }} \times 100$

The lowest volume quartile is defined as one-fourth of the cups that contained the lowest catch volumes. In Figure 1, this would be volumes of $35+37+$ $37+39=148 / 4=37$. The average of the lowest volume quartile, 37 , is divided by the average volume, 43 , to yield a DU of 86. Cups with straight sides or tapered sides can be used as long as all cups are exactly the same. For cups with straight sides, depth of water can be measured in the cups and reported in inches (Haman and Yeager, 2003a). When cups have straight up and down sides (top with same diameter as bottom) you can measure depth of water directly in the cup. If the cup does not have straight sides, measure volume and convert to depth based on top diameter.

Application rate can be calculated directly from the average depth of water in each cup (Haman and Yeager, 2003b). However, when cups with tapered sides are used, the depth of water in each cup must be calculated based on the top area of the cup and the volume of water in each cup.

\section{Microirrigation}

Many nurseries use microirrigation for plants grown in containers $>20$ L (5.3 gal) volume (Beeson and Knox, 1991). Garber et al. (2002) found in a 2001 survey of 102 container nurseries in Georgia that smaller containers 


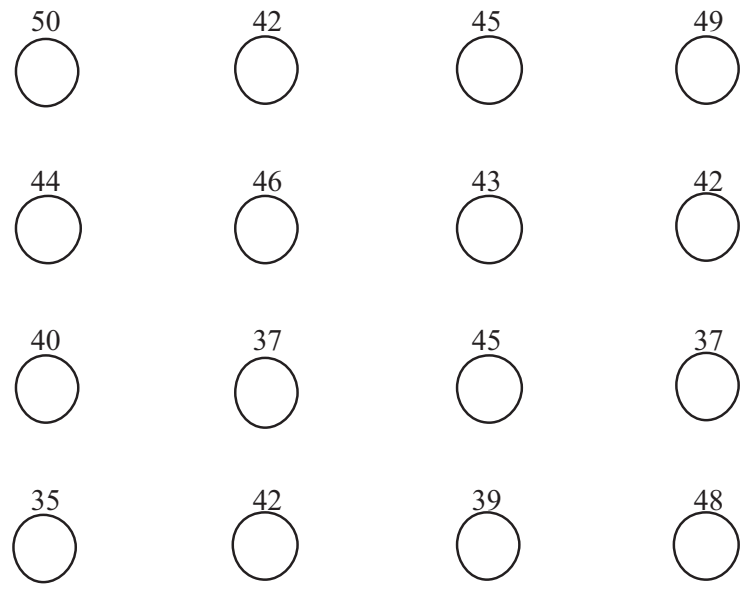

Fig. 1. Examples of volumes collected per cup from a 16-cup test for irrigation distribution uniformity. Cups were laid out in the grid pattern as indicated between four overhead sprinklers.

(\#1, \#3 and \#5) (ANSI, 1996) are irrigated by overhead methods and \#7 (49\%), \#15 (85\%), and \#25 (75\%) (ANSI, 1996) were irrigated by directed application methods (drip/ spray). The use of directed methods with larger containers is a desirable practice because the larger containers intercept the lowest percentages of applied overhead irrigation (Garber et al., 2002). However, \#1, \#3, and \#5 containers, irrigated by overhead, represent the largest segment of the industry's production area (Garber et al., 2002). Use of directed irrigation methods in large containers, outside the southern states, is thought to be much less than those percentages found in the Georgia survey.

Use of microirrigation significantly increases application efficiency compared with overhead irrigation. Microirrigation generally consists of frequent applications of water at very low rates to specific areas of substrate (Mathers, 2003). Emitters, rather than nozzles, are used in microirrigation systems. These emitters may be point source, line source (tapes, soaker hose, etc.), or microsprinkler types (Regan, 1997). Microirrigation can significantly reduce irrigation runoff (Green and Rost, 1985), but the system must be properly maintained. Sand or other filtration systems are used to clean water and minimize emitter clogging. Filters must be cleaned, emitters checked for debris, and emitter flow measured to ensure correct volume of water is applied, and water pressures monitored (Regan, 1997) to ensure pressure regulators are functioning properly. When compared to overhead sprinkler irrigation, microirrigation can reduce operating costs, reduce the potential for foliage disease and residues due to alkaline water, and improve fertilizer application efficiency (Green and Rost, 1985). A combination of microirrigation and overhead sprinkler irrigation allows for maximum flexibility of production space.

UNIFORM MICROIRRIGATION APPLICATION. Microirrigation uniformity can be determined by recording the time to fill a minimum of 18 bottles with emitters selected randomly throughout the irrigated area. The sum of lowest and highest one-sixth times to fill the same size bottle are fitted to a nomograph. Thus, the number of bottles filled must be a multiple of six. Details are given by Haman and Yeager (2003c).

\section{Schedule irrigation}

Although increasing water application uniformity is an obvious way to save water, irrigation scheduling may not be so obvious. Both can help to conserve water and reduce runoff. Scheduling irrigation means applying only the amount of water that is needed, when it is needed. For container pro- duction systems, the decision to apply water is usually done manually because of the lack of reliable automation. Regan (1999) found that proper irrigation scheduling would save approximately $25 \%$ of water use.

The ideal way to schedule irrigations is by determining how much water the plants are using and then replenish that amount (Regan, 1999). Scheduling is easier if plants with similar water demands or water needs are grouped under the same irrigation zone (Regan, 1997). Burger et al. (1987) reported that nursery managers can determine crop evapotranspiration $\left(\mathrm{ET}_{\text {crop }}\right)$ by watering the container with the crop of interest, wait $1 \mathrm{~h}$ and then weigh, wait for $24 \mathrm{~h}$ and then reweigh. This determines the amount of water lost by evaporation and transpiration or the amount of irrigation water that must be put in the container to replenish plant demand. A crop coefficient $(\mathrm{K})$ is used to relate the $\mathrm{ET}_{\text {crop }}$ and $\mathrm{ET}_{\mathrm{o}}$, potential evapotranspiration $\left(\mathrm{ET}_{\text {crop }}=\mathrm{ET}_{\mathrm{o}} \times \mathrm{K}\right) \cdot \mathrm{ET}_{\mathrm{o}}$ values can be obtained from weather station data. Crop coefficients for most container plants have not been determined. Crop coefficients are used to adjust irrigation volume to specific production practices and crop characteristics. Crop coefficients are different for each growth and development stage of a crop and, generally, larger plants use more water. Fast-growing plants may also use more water. Plants may use less water during the crop establishment phase, if the plant has "fixed-growth" or one flush per season, and when the plant is entering dormancy (Regan, 1997). Variations in water use also occur within and between major plant groups (conifers, deciduous, broadleaf evergreens), whether plants are newly planted or established, and depending on canopy characteristics (Beeson and Yeager, 2003). The production practice of spacing plants influences container water requirements and crop coefficients (Burger et al., 1987) and, generally, plants use more water when the spacing is increased between containers. Crop coefficients are very specific to size of plant and species, spacing, and production surface. Based on the species, container-grown crops can be categorized as heavy, moderate, or light water users (Burger et al., 1987) and grouped into irrigation zones by water requirement.

Grouping PLANTS. Grouping 
plants according to their water use and scheduling irrigation can conserve water. A crop's water requirement is the amount of water needed to replace the water lost from evapotranspiration. Water use is strongly influenced by climate, production practices, and crop characteristics (Regan, 1999). Generally, most nursery crops use more water on clear, dry, and windy days than on days that are humid, overcast, and calm. Regan (1999) and Henley et al. (2003) have developed a list of plants grouped by water requirement.

Leaching FRACtion. Another way to improve application efficiency by scheduling is to control the volume of water leached. The leaching fraction $[(\mathrm{LF})=$ volume leached/volume applied] found to maximize growth of 'Skogholm' bearberry cotoneaster (Cotoneaster dammeri) ranged from 0.12 to 0.25 (Warren and Bilderback, 2002). Conventional container culture dictates that some leaching is likely required to prevent salt buildups. One way to make significant gains in water conservation is to approach zero leaching fractions, and researchers are now exploring this possibility (Warren and Bilderback, 2005).

Cyclic irrigation can reduce water use by approximately 25\% (Sneed, 1996). Various researchers working with different types of irrigation systems and container substrates have found a range of water savings. Using an overhead system with a 3 pine bark: 1 peat substrate, Fare et al. (1994) found 34\% water savings with cyclic irrigation. Karam and Niemiera (1994) determined that water application efficiency was $4 \%$ higher for cyclic overhead irrigation than for one continuous application, while Lamack and Niemiera (1993) found that cyclic irrigation delivered with spray stakes was $11 \%$ to $17 \%$ more efficient than one continuous application to a pine bark substrate.

Cyclic irrigation can vary from two to 12 cycles/d, but about three cycles/d are adequate (Sneed, 1996). The key to increasing water application efficiency using cyclic irrigation is time-averaged application rate (TAAR) (Warren and Bilderback, 2005). The number of cycles used is of less importance. TAAR includes the rate of application, duration of application, and the interval between applications (Warren and Bilderback, 2005). If a grower is currently applying $12.7 \mathrm{~mm}$
( 0.5 inch) of water by irrigating for 60 min, with cyclic irrigation this could be reduced by $25 \%$, with three cycles of $15 \mathrm{~min}$ each or five cycles of $9 \mathrm{~min}$ each. Water would be saved with the reduced application time because not as much water would leave the container as runoff compared to $60 \mathrm{~min}$ of container irrigation. Hence, more water stays in the container and there is a more uniform water distribution in the container.

Time of Irrigation. The Southern Nursery Association best management practices (BMPs) recommend to irrigate predawn (PD) whenever possible (Yeager et al., 1997). Early morning irrigation reduces evaporative water losses that can occur as the day progresses. With early morning irrigation, leaves have time to dry during the day and the risk of foliar disease should be reduced. Also, winds are generally lower during the morning and increase as the day progresses. Overhead irrigation water is delivered in a more uniform pattern during periods of low winds.

Warren and Bilderback (2002) dispute the PD irrigation timing. They were working with 'Skogholm' bearberry cotoneaster in an 8 pine bark: 1 sand substrate and irrigated with four different cyclic timings: 0200, 0400, 0600 HR (PD); 0600, 0900,1200 (АМ); 1200, 1500, 1800 (PM); or $0600,1200,1800$ (AD). They found that the PM irrigation resulted in increased growth compared to all other timings. The PM timing resulted in a $69 \%$ growth increase over the PD irrigation. Another interesting finding was that although water use of the plant was best with PM watering, the best time to irrigate to save water was still PD (Warren and Bilderback, 2002). Although the plants utilized water best with the PM watering, this was not enough to compensate for the water lost to evaporation compared to the PD watering. Therefore, if water conservation is the prime objective, $\mathrm{PD}$ watering is still the recommended time.

Beeson (1992) showed that growth reduction resulted from $\mathrm{PD}$ overhead watering compared to irrigation applied throughout the day. Beeson (1992) found that when japanese privet (Ligustrum japonicum), thorny elaeagnus (Elaeagnuspungens), 'Fashion' azalea (Rhododendron sp.), and fraser photinia (Photinia $\times$ fraseri) in
10.4-L (2.75 gal) containers were irrigated PD via overhead irrigation vs. cyclic irrigation three or four times a day, shoot height was significantly reduced for all four species. The azalea exhibited a 39\% decrease in growth index when irrigated $P D$ via overhead watering vs. cyclic irrigation, and thorny elaeagnus exhibited a $23 \%$ reduction in growth indexes (Beeson, 1992).

\section{Substrate amendments}

Substrate amendments such as peat may be used to increase the water holding capacity of substrates, thus decreasing leaching. Bilderback et al. (1982) found that amending a peanut hull substrate with Canadian peat ( $1: 1$ by volume) instead of pine bark resulted in a significant increase in available water in the substrate. Owens et al. (2003) found they could reduce water use by using calcined clay in place of sand in a pine bark: sand substrate. Over a 120 -d production time, they saved 23 L (6.1 gal) per container or 950,000 $\mathrm{L} \cdot \mathrm{ha}^{-1}$ (101,565 gal/acre). They were using a 2:1 structure, calcined clay with 24-48-mesh particle size at $8 \%$ by volume in the pine bark. Because pine bark substrates are relatively poor at holding water, further work into substrate amendments would be justified to potentially increase water savings.

\section{Heat load}

Generally, cultural practices that reduce root injury and heat load on the container will reduce water use. Cultural practices that include using shading, border rows of substratefilled containers, larger plants to shield inside rows from wind and temperatures, companion plantings of larger plants to produce an overstory that will shade smaller-sized plants, and mulches (Davies, 1988) may reduce container heat loads. Heat stress in black plastic containers occurs because of the large influx of energy from the sun combined with insufficient loss of the incoming heat (Ruter, 1999). In current nursery culture, shadecloth is used to reduce light transmission and reduce heat stress to containerized plants. However, retractable roof production can be used to reduce heat stress without reducing light transmission (Svenson, 2000). The retractable films allow more light diffusion than conventional polyethylene films and more light transmission than black 
shadecloths without the heat buildup (Svenson, 2000). Cooler substrate temperatures experienced in retractable roof houses protect plant roots from damage, leading to improved shoot growth and reduced substrate evaporation so substrate moisture is available to support transpiration and further growth improvements (Svenson, 2000). Canopy leaves also are cooler under polyethylene films with diffuse light, which can increase photosynthetic rates on hot days (Svenson, 2000). Also, diffuse light is intercepted more efficiently than direct light, leading to increased photosynthetic rates. Due to the protection provided to the root systems and improved photosynthetic capacity of the plants, growers are reporting cutting their production times of certain crops in half. An Oregon nursery reported using half the irrigation water that was used in conventional container production on outside gravel beds (Woodburn Nursery and Azaleas, personal communication). This is probably due in part to reduction of root-zone temperature.

\section{Recycle runoff}

Microirrigation and scheduling irrigation, including cyclic irrigation, have been mentioned above as ways to reduce runoff. Although increasing water application uniformity is an obvious way to save water, irrigation scheduling may not be so obvious. Both can help to conserve water and reduce runoff. These methods can be important where land area is limited and water storage structures are not possible. Because a significant reduction in runoff is not always possible with scheduling, collection structures are used to capture runoff water. The collection structure may serve as a reservoir of irrigation water for times when supply is limited, or the primary purpose of the collection structure may be to prevent nutrient discharge from the property or at least mitigate the collected water before discharge. The size of the collection structure will vary depending upon the primary purpose of the structure. For example, if runoff water mitigation is the primary purpose, then several small collection structures would be better than one large structure, whereas one very deep structure would be best for water storage.

Collection structure capacity should accommodate about $90 \%$ of the irrigation water applied (Yeager et al., 1997). However, the production area surface material, underlay, and slope influence the amount of runoff in addition to irrigation application rate, size and number of plants per area, plant irrigation capture, substrate physical properties, and ambient conditions. The U.S. Department of Agriculture, Natural Resources Conservation Service (USDA/NRCS) can assist with specifications for grading and constructing collection structures.

\section{Conclusions}

There are many choices that can be made today in nursery irrigation system components, designs, and operation. The plant's specific needs are often overlooked when nursery irrigation systems are designed, but as water cost and water restrictions increase, these will become critical. Proper design of overhead and microirrigation systems will ensure uniform delivery needed to achieve maximum application efficiency when the appropriate amount of irrigation water is scheduled, based on plant demand. Additionally, using substrate amendments that retain water by reducing the substrate temperature, and recycling runoff, can conserve water.

\section{Literature cited}

American National Standards Institute. 1996. American standards for nursery stock. Amer. Assn. Nurserymen, Washington, D.C.

Beeson, R.C., Jr. 1992. Restricting overhead irrigation to dawn limits growth in container-grown ornamentals. HortScience 27:996-999.

Beeson, R.C., Jr. and G.W. Knox. 1991. Analysis of efficiency of overhead irrigation in container production. HortScience 26:848-850.

Beeson R.C., Jr. and T.H. Yeager. 2003. Plant canopy affects sprinkler irrigation application efficiency of container-grown ornamentals. HortScience 38:1373-1377.

Bilderback, T.E., W.C. Fonteno, and D.R. Johnson. 1982. Physical properties of media composed of peanut hulls, pine bark, and peatmoss and their effects on azalea growth. J. Amer. Soc. Hort. Sci. 107:522-525.

Burger, D.W., J.S. Hartin, D.R. Hodel, T.A. Lukaszewski, S.A. Tjosvold, and S.A. Wagner. 1987. Water use in California's ornamental nurseries. Calif. Agr. 41:7-8.
Davies, F.T. 1988. Plant water relations: Effect on the growth of woody ornamental plants. J. Rio Grande Valley Hort. Soc. 41:29-31.

Fare, D.C., C.G. Gilliam, and G.J. Keever. 1994. Cyclic irrigation reduces container leachate nitrate-nitrogen concentration. HortScience 29:1514-1517.

Furuta, T. 1974. Environmental plant production and marketing. lst ed. Cox Publ., Arcadia, Calif.

Garber, M.P., J.M. Ruter, and J.T. Midcap. 2002. Survey of container nursery irrigation practices in Georgia. Proc. Southern Nursery Assn. Res. Conf. 47:598-600.

Green, J.L. and B. Rost. 1985. Overhead vs. low volume irrigation. Greenhouse Manager April:84, 86-89.

Haman, D.Z., A.G. Smajstrla, and D.J. Pitts. 2003. Uniformity of sprinkler and microirrigation systems for nurseries. Univ. Fla. Ext. Bul. 96-10. 1 Oct. 2004. <http://edis.ifas.ufl.edu/AE090>.

Haman, D.Z. and T.H. Yeager. 2003a. Field evaluation of container nursery irrigation systems: Uniformity of water application in sprinkler systems. Univ. Fla. Ext. Fact Sheet 98-2. 1 Oct. 2004. <http://edis. ifas.ufl.edu/AE194>.

Haman, D.Z. and T.H. Yeager. 2003b. Field evaluation of container nursery irrigation systems, part 2: Measuring application rate. Univ. Fla. Ext. Fact Sheet AE261. I Oct. 2004. <http://edis.ifas. ufl.edu/AE097>.

Haman, D.Z. and T.H. Yeager. 2003c. Field evaluation of container nursery irrigation systems: Measuring uniformity of water application in microirrigation systems. Univ. Fla. Ext. Fact Sheet 98-1. 1 Oct. 2004. <http://edis.ifas.ufl.edu/AE193>.

Henley, R.W., T.H. Yeager, and R.C. Beeson, Jr. 2003. Opinions on plant irrigation requirements. Univ. Fla. Ext Fact Sheet ENH-148. I Oct. 2004. <http://edis. ifas.ufl.edu/EP067>.

Karam, N.S. and A.X. Niemiera. 1994. Cyclic sprinkler irrigation and pre-irrigation substrate water content affect water and $\mathrm{N}$ leaching from containers. J. Environ. Hort. 12:98-202.

Lamack, W.F. and A.X. Niemiera. 1993. Application method affects water application efficiency of spray stake-irrigated containers. HortScience 28:625-627.

Mathers, H.M. 2003. Top 10 ways to conserve water. Nursery Mgt. Production 19(11):30-32, 33-35.

Owens, J.S., Jr., S.L. Warren, and T.E. Bliderback. 2003. Clay amended pine bark decreases water use and phosphorus loss. 


\section{WORKSHOP}

Proc. Southern Nursery Assn. Res. Conf. 48th Annu. Rpt. p. 20-23.

Regan, R. 1997. Grouping containergrown plants by water use. Digger $4 \mathrm{l}(6): 24-27$.

Regan, R. 1999. Nursery irrigation scheduling, p. 1-8. Proc. 2nd Annu. Nursery Growers Short Course. Wilsonville, Ore.

Ruter, J.M. 1999. Fiber pots improve survival of 'Otto Luyken' Laurel. Proc. Southern Nursery Assn. Res. Conf. 44:53-54.

Sneed, R. 1996. Pumps, pipes and consultations. Amer. Nurseryman June: 45-46, $48,50-53$.

Svenson, S.E. 2000. Diffusion confusion: Comparing shadecloth and poly film for shading nursery crops. Nursery Mgt. Production 16(8):39-44.

Warren, S.L. and T.E. Bilderback. 2002. Timing of low-pressure irrigation affects plant growth and water utilization efficiency. J. Environ. Hort. 20:184-188.

Warren, S.L. and T.E. Bilderback. 2005. More plant per gallon: Getting more out of your water. HortTechnology 15:14-18.

Weatherspoon, D.M. and C.C. Harrell. 1980. Evaluation of drip irrigation for container production of woody landscape plants. HortScience 15:488-489.

Yeager, T.H.C.H. Gilliam, T.E. Bilderback, D.C. Fare, A.X. Niemiera, and K.M. Tilt. 1997. Best management practices guide for producing container-grown plants. Southern Nursery Assn., Atlanta, Ga. 